\title{
Potential future land use threats to California's protected areas
}

\author{
Tamara Sue Wilson • Benjamin Michael Sleeter • \\ Adam Wilkinson Davis
}

Received: 28 January 2014/Accepted: 16 August 2014/Published online: 11 September 2014

(C) The Author(s) 2014. This article is published with open access at Springerlink.com

\begin{abstract}
Increasing pressures from land use coupled with future changes in climate will present unique challenges for California's protected areas. We assessed the potential for future land use conversion on land surrounding existing protected areas in California's twelve ecoregions, utilizing annual, spatially explicit $(250 \mathrm{~m})$ scenario projections of land use for 2006-2100 based on the Intergovernmental Panel on Climate Change Special Report on Emission Scenarios to examine future changes in development, agriculture, and logging. We calculated a conversion threat index (CTI) for each unprotected pixel, combining land use conversion potential with proximity to protected area boundaries, in order to identify ecoregions and protected areas at greatest potential risk of proximal land conversion. Our results indicate that California's Coast Range ecoregion had the highest CTI with competition for extractive logging placing the greatest demand on land in close proximity to existing protected areas. For more permanent land use conversions into agriculture and developed uses, our CTI results indicate that protected areas in the Central California Valley and Oak Woodlands are most vulnerable. Overall, the Eastern Cascades, Central California Valley, and Oak Woodlands ecoregions had the lowest areal percent of protected lands and highest conversion threat values. With limited resources and time, rapid, landscape-level analysis of potential land use threats can help quickly identify areas with higher conversion probability of future land use and potential changes to both
\end{abstract}

Editor: Elena M. Bennett.

T. S. Wilson $(\varangle) \cdot$ B. M. Sleeter · A. W. Davis

Western Geographic Science Center, US Geological Survey, 345 Middlefield Road, MS-531, Menlo Park, CA 94025, USA e-mail: tswilson@usgs.gov habitat and potential ecosystem reserves. Given the broad range of future uncertainties, LULC projections are a useful tool allowing land managers to visualize alternative landscape futures, improve planning, and optimize management practices.

Keywords Land use change - Conversion threat index . Oak woodlands - Coast range - IPCC scenarios · Future projections $\cdot$ Ecoregions $\cdot$ Protected areas

\section{Introduction}

In this century, human land use will likely present a greater threat to biodiversity than climate change (Dale 1997; Sala et al. 2000). Land use has already transformed more than half of the earth's land surface in the last 300 years (Turner et al. 1990; Vitousek et al. 1997). Changes in land use and land cover (LULC) have been linked to habitat loss (Soule 2001; Seabloom et al. 2002), species extinction (Davies et al. 2006), changes in species diversity (Rittenhouse et al. 2012), declines in water (Foley et al. 2005) and air quality (Romero et al. 1999; Ross et al. 2006), carbon dioxide emissions (Houghton and Hackler 2001), and climate change at regional and global scales (Bonan 1997; Pielke et al. 2002; Lawrence and Chase 2010; Pitman et al. 2011). Continued land use change is expected in coming decades, as human demand for food, fiber, energy, and urban development continue to grow with increasing population. Complex interactions between changing demographics, policies, economics, technologies, and climate will also influence and determine future LULC (Arnell et al. 2004; Bierwagen et al. 2010). While many environmental protections and management strategies are currently in place to protect landscapes, increasing land-use intensity could 
further isolate protected areas, inhibiting landscape and biological connectivity (Fischer and Lindenmayer 2007) and diminishing habitat quality (Hansen and Rotella 2002). In California, competition between land use and land preservation is already high and will only intensify in coming decades.

While protected areas are intended to safeguard biodiversity, they do not function in isolation of regional ecological flows and processes altered by human activity (Hansen and DeFries 2007). Land use in areas adjacent to, and at varying proximity from protected areas can influence the value and success of protected areas as a conservation method (Hansen et al. 2002; Joppa et al. 2008; Radeloff et al. 2010; Hamilton et al. 2013). Land use adjacent to protected areas can have direct impacts on biodiversity via habitat loss, increased fragmentation and isolation, reduced dispersion capability, and increased invasions by nonnatives. Non-local land uses can have broad reaching indirect impacts as well. Air pollution from large metropolitan areas impacts ecosystems throughout California (Fenn et al. 2003) while logging activity impacts slope stability and elevated sediment loads in streams resulting in habitat degradation (Neary and Hornbeck 1994) and altered biogeochemical cycling (Nave et al. 2010). Agriculture activities in California's Central Valley have been implicated in elevated nitrogen pollution levels in Sequoia National Park (Bytnerowicz et al. 2002) and throughout the western Sierra Nevada (Takemoto et al. 2001), and have driven widespread increases in nonpoint source pollution of surface and groundwater statewide (Charbonneau and Kondolf 1993). Non-local pesticide use in summer has been shown to transport in air masses to lower elevations along the western Sierra escarpment as well (LeNoir et al. 2009). Human landuse in the coming decades will likely continue to directly and indirectly disrupt ecological processes.

A significant limitation in our current understanding is how land use and increasing land use intensity outside of protected areas and near protected area boundaries can decrease the overall effectiveness of protected areas as a tool for biodiversity conservation (Hansen et al. 2014). Examining landscapes threatened by current and future land-use activities have been suggested as a method to assign vulnerability indicators to regions already designated as protected (Theobald 2003). In the United States, the National GAP Analysis Program (GAP) categorized all lands in the United States by management status to delineate protected areas, areas subject to limited or unlimited land use, and those privately held (US Geological Survey GAP 2012). A much needed addition to protection status categories is a landscape vulnerability category targeting land use change threat, as lands with the highest levels of protection (i.e. wilderness areas in the US) are still subject to internal and external threats (Wade et al. 2011; Cole and
Landres 1996). Such an approach would incorporate biodiversity threat into biological assessments (Theobald 2003). Vulnerability indicators such as future population growth and presence of roads have already been used to rate the potential vulnerability of plant communities and to set conservation priorities (White et al. 1997; Stoms 2000; Menon et al. 2001; Radeloff et al. 2010). However, selection of appropriate vulnerability indicators is regionally dependent on the land use threat (e.g. development, agriculture, logging) and constrained by spatial data limitations (Stoms 2000). Land-use conversion potential is also a key factor in the site selection process for new protected lands (Newburn et al. 2005), helping to identify protected land vulnerability (Margules and Pressey 2000) and guide management strategies (Defries et al. 2007). In areas with a high likelihood of land use conversion there is a positive correlation with cost of land protection (Newburn et al. 2005). Development of landscape vulnerability indicators driven by scenarios of land use conversion potential is needed in order to effectively manage protected areas under future land use change.

Recent advancements in spatial data availability and land use projection modeling have improved our ability to examine future scenarios of land use change. Spatially explicit LULC scenarios have been used to analyze the impacts of land conversion on biodiversity (Luoto et al. 2007), hydrology (Strayer et al. 2003), carbon fluxes (Zhao et al. 2013), and climate change (Pielke et al. 2002). Scenario modeling has also identified land use as the leading driver of change in global biodiversity by the year 2100 (Sala et al. 2000), with greatest biodiversity change projected in the Mediterranean biome, of which California is a part (Klausmeyer and Shaw 2009). Given the broad range of future uncertainties, LULC projections are a useful tool allowing land managers to visualize alternative landscape futures, improve planning, and optimize management practices (Heistermann et al. 2006). National and regional LULC projections have recently been published for the United States (Wear 2011; Zhu 2011; Radeloff et al. 2012; Sleeter et al. 2012b; Sohl et al. 2012a; Wilson et al. 2012; Sohl et al. 2014).

Here we present spatially explicit LULC projections, based on four Intergovernmental Panel on Climate Change (IPCC) emission scenarios for California's twelve ecoregions, and examine land use conversion threats (i.e. from development, agriculture, and logging) in proximity to existing protected areas. Our goal was to identify ecoregions with protected areas at greatest risk from proximal land use conversion to help guide future conservation planning efforts. Rapid, landscape level analysis of multiple land use threats to biodiversity in areas surrounding conservation lands are needed if effective, long-term management strategies are to succeed (Wilson et al. 2005, McDonald et al. 2007). 


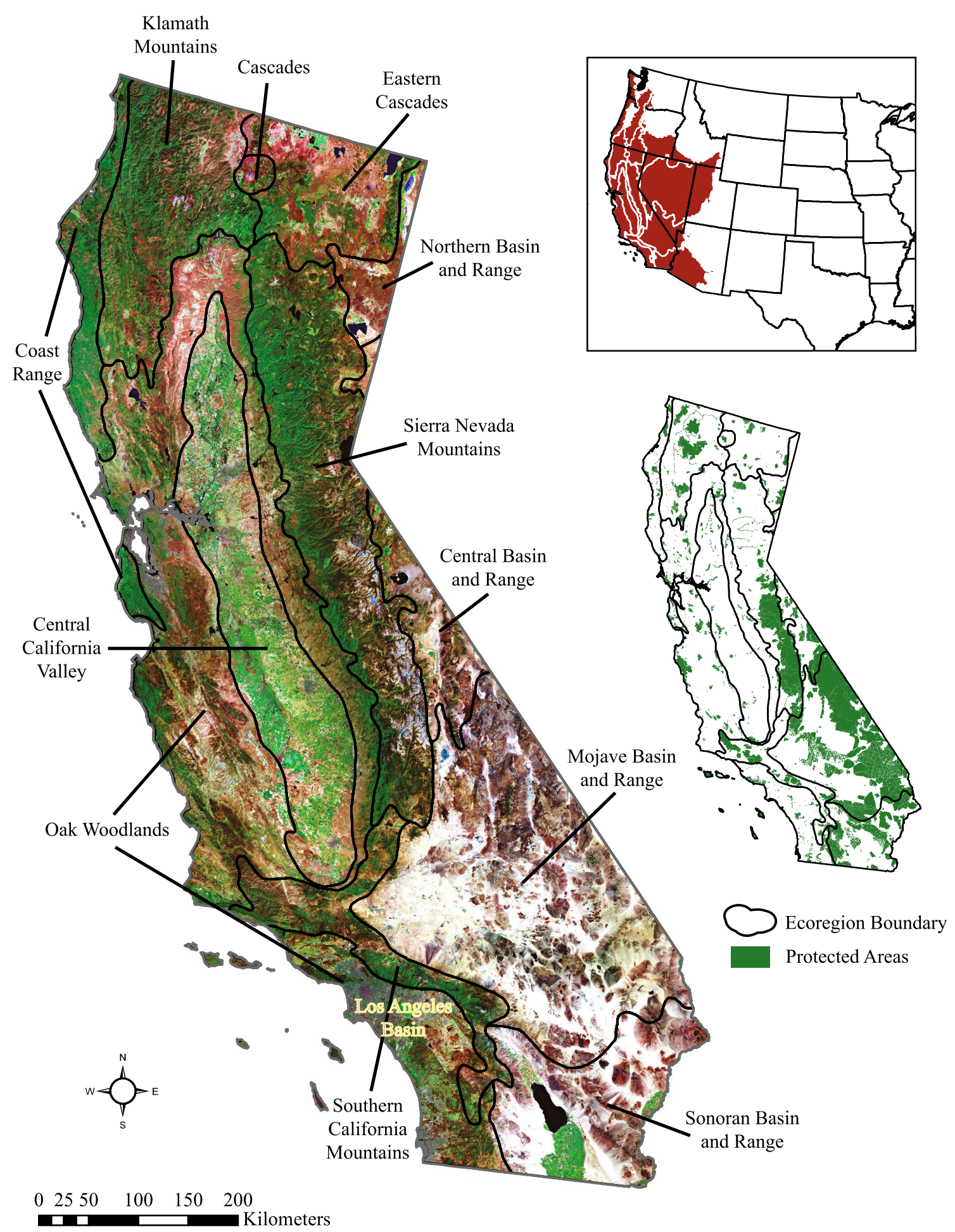

Fig. 1 Ecoregions and protected areas in California. Inset map of the western United States shows the geographic extent of California's ecoregions 


\section{Materials and methods}

\section{Study area}

California is one of the most diverse states in the nation in terms of economics, demographics, natural resource capacity, land use, and biophysical variability. It was home to an estimated 38 million in 2012 (US Census Bureau 2013) and is projected to grow to 52.7 million by 2060 (State of California 2013). A majority of the state lies within the California Floristic Province, a designated biodiversity hotspot with a high concentration of endemic species (Myers 1990). Twelve unique US Environmental Protection Agency (EPA) Level III ecoregions (US EPA 1999) fall within state boundaries, spanning approximately $408,230 \mathrm{~km}^{2}$ (Fig. 1). The EPA Level III ecoregions represent semi-continuous regions with similar patterns of biotic, abiotic, aquatic, and human land-use characteristics and have proven to be a useful framework for collecting and synthesizing information about LULC change (Omernik 1987; Gallant et al. 2004) and species diversity (Rittenhouse et al. 2012). California's current LULC composition is an estimated $49 \%$ grassland/shrubland, $27 \%$ forest, $12 \%$ agriculture, $4 \%$ developed, and $8 \%$ other LULC (i.e. water, barren, mining, wetlands, ice/snow), while $0.6 \%$ is logged at any given time.

Future projections of land use and land cover change

We utilized existing, spatially explicit LULC change projection scenarios developed for Level III ecoregions of the conterminous US (Sohl et al. 2014; data available

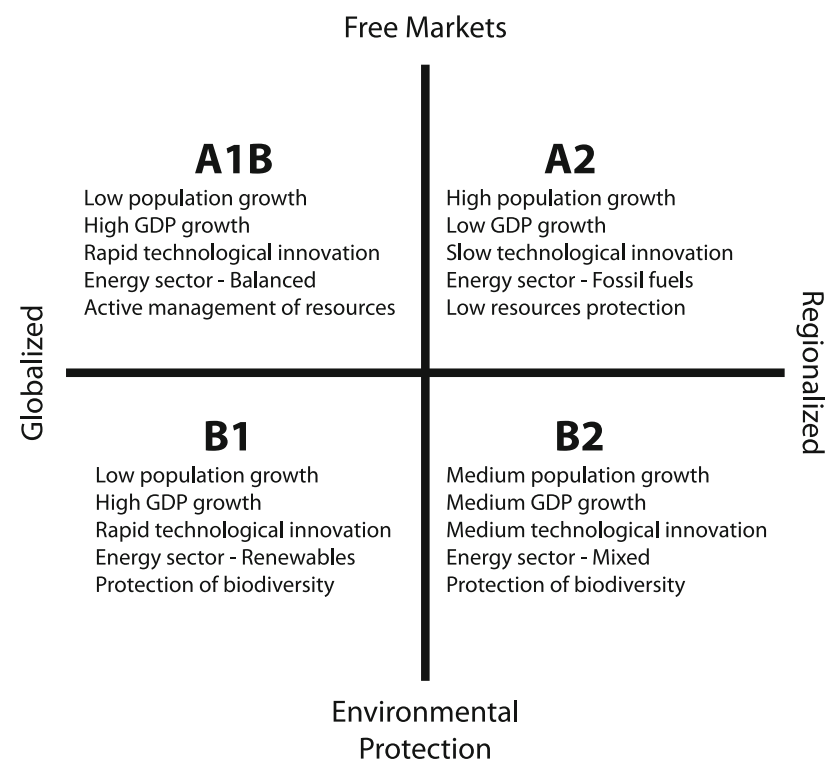

Fig. 2 Characteristics of the major driving forces behind the Intergovernmental Panel on Climate Change's Special Report on Emission Scenarios four scenario families (from Sleeter et al. 2012a) online http://landcover-modeling.cr.usgs.gov) following future socio-economic scenarios (A1B, A2, B1, B2) documented in the IPCC's Special Report on Emissions Scenarios (SRES) (Nakicenovic and Swart 2000). SRES scenarios are grounded in socioeconomics and have been widely used by the global change community to understand future environmental conditions resulting from climate change (Arnell et al. 2004; Gaffin et al. 2004; Verburg et al. 2006, Rounsevell et al. 2006; van Vuuren et al. 2007). The SRES scenarios describe future developments in major driving forces of greenhouse-gas emissions, including population, economics, technological innovation, and energy use, representing a wide range of LULC futures (Fig. 2).

The SRES scenarios were downscaled from half-by-half degree grid cells to 250-m cells using an accounting model in combination with an Integrated Assessment Model (IMAGE Team 2001), Landsat-based land use histories (Sleeter et al. 2010, 2013), and expert knowledge. Changes in LULC "demand" were projected at 5-year intervals out to 2100 for 16 LULC classes, including 11 natural land cover classes (water, barren, grassland, shrubland, deciduous forest, evergreen forest, mixed forest, herbaceous wetland, woody wetland, ice/snow) and five land use classes (developed, mining, logging, cropland, hay/pasture). For a complete description of downscaling methods, see Sleeter et al. (2012a).

Spatially explicit modeling of scenarios

We utilized annual projections of LULC at 250-m resolution for the years 2006-2100 for each IPCC SRES scenario modeled using the FOREcasting SCEnarios of Land-use Change (FORE-SCE) model (Sohl et al. 2007, 2012a, b, 2014). The FORE-SCE model uses a patch-based modeling approach, placing individual patches on the landscape until annualized scenario "demand" from the accounting model was met. Patch characteristics were determined by historic, ecoregion-based LULC change estimated by the US Geological Survey's Land Cover Trends analysis (Sleeter et al. 2013). Spatial placement of new LULC patches was dictated by probability surfaces generated from logistic regression analysis of each LULC class against 21 different biophysical, climatic, geographic, and cultural variables ( $\alpha=0.05<>0.001 ;$ Table 1$)$. The model also tracked annual forest stand age. Initial stand age was generated from LANDFIRE Vegetation Change Tracker (VCT) (Huang et al. 2010) and Forest Inventory and Analysis (FIA) data (US Forest Service 2011). Stand age was reset to "0" whenever a forested pixel was harvested. Minimum forest harvest age was set at 45 years. Forest pixels aged continuously until a harvest occurred. FORE-SCE did not model natural mortality or natural disturbances. Scenario-based 
Table 1 Independent variables used in the logistic regression analysis to produce probability of land use and land cover occurrence, organized by biophysical and cultural categories (modified from Wilson et al. 2012)

\begin{tabular}{|c|c|}
\hline Category & Variable \\
\hline Topographic & 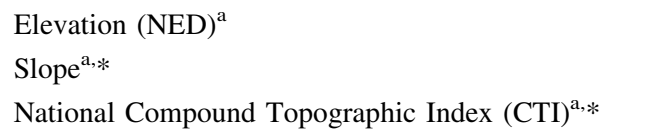 \\
\hline Geographic & $\begin{array}{l}\text { Latitude (XCOORD) } \\
\text { Longitude (YCOORD) }\end{array}$ \\
\hline Cultural & $\begin{array}{l}\text { Population Density (POPDEN) } \\
\text { Housing Density (HOUSEDEN) } \\
\text { Distance to City (DISTCITY) }^{\mathrm{b},+} \\
\text { Urban Window Count (URBAN) }^{\mathrm{b},++} \\
\text { Distance to Road (DISTROAD) } \\
\text { Distance to Railroad (DISTRAIL) } \\
\text { Dis,+ }\end{array}$ \\
\hline Biophysical & $\begin{array}{l}\text { Available Water Content (AWC) } \\
\text { Soil Organic Carbon }\left(\text { SOC) }^{\mathrm{d}}\right. \\
\text { Crop Capability (CROPCAP) }^{\mathrm{d}} \\
\text { Hydric Soils (HYDRIC) }^{\mathrm{d}} \\
\text { Distance to Water (DSTWATER) })^{\mathrm{c},+} \\
\text { Distance to Stream (DISTSTREAM) } \\
\text { c,+ }\end{array}$ \\
\hline Climate & $\begin{array}{l}\text { Maximum July Temperature (MAXTEMP) } \\
\text { Minimum January Temperature (MINTEMP) } \\
\text { Average Temperature ( } 30 \text { year average, AVETEMP) } \\
\text { Average Precipitation ( } 30 \text { year average, } \\
\text { AVEPRECIP) }\end{array}$ \\
\hline
\end{tabular}

* Derived from the US Geological Survey's National Elevation Dataset, more information available at: http://edna.usgs.gov/Edna/ edna.asp

+ Distance to variables calculated in ArcGIS environment in meters away from feature line or boundary

${ }^{++}$Calculated as average density per concentric 50 pixel radius values based on US Census population density

${ }^{\text {a }}$ US Geological Survey (2006)

${ }^{\text {b }}$ US Census Bureau (2000)

c US Geological Survey (2012)

d Natural Resources Conservation Service (2011)

${ }^{\text {e }}$ Maurer et al. (2007). Based on the IPCC-SRES A1B scenario

"demand," development of probability surfaces, designation of forest cutting cycles, and parameterization of all other model components were done independently for each Level III ecoregion. Complete details on scenario development and methodology are described in Sleeter et al. (2012a) and Sohl et al. (2007, 2012b). Validation of results is discussed in Sleeter et al. (2012a) and model limitations and uncertainty are discussed in Sohl et al. (2014).

Protected areas

The LULC modeling approach described above utilized the Protected Areas Database of the United States (PAD-US) produced by the USGS National Gap Analysis Program (GAP) (US Geological Survey 2012). Areas categorized as GAP Status 1 or 2 (hereafter termed protected areas) as well as federal military bases were not allowed to undergo land conversion in any scenario. GAP Status 1 areas are defined as having permanent protection from conversion of natural land cover and a mandated management plan in operation to maintain a natural state within which disturbance events (of natural type, frequency, intensity, and legacy) are allowed to proceed without interference or are mimicked through management. Areas with GAP Status 2 have permanent protection from conversion of natural land cover and a mandated management plan in operation to maintain a primarily natural state, but which may receive uses or management practices that degrade the quality of existing natural communities, including suppression of natural disturbance (US Geological Survey GAP 2012). Our analysis assumes existing protected areas remain constant through 2100 .

Land conversion potential and conversion threat index mapping

We utilized the annual, spatially explicit (250 m) LULC projections for California in our spatial analysis. We collapsed the original 16 LULC classes into the following 9 modified Anderson Level I LULC classes (Anderson et al. 1976): water, barren, grassland/shrubland, forest, wetland, developed, mining, logging, and agriculture. The deciduous, evergreen, and mixed forest classes were merged into a single forest class. The grassland and shrubland classes were also grouped. Since logging demand was assigned by ownership type in the original dataset, forested pixels projected to be logged were classified by ownership categories: private, National Forest, and other public land. The cropland and hay/pasture classes were combined into a single agriculture class.

We calculated total projected LULC change at the state level for each modeled year (2006-2100) and scenario, accounting for all pixels converting LULC class one or multiple times. We mapped total forest footprint and extracted forest stand age values over the model period, for ecoregions with present day logging (i.e. Oak Woodlands and Southern California Mountains not included). We calculated total onshore, in-state protected land area extent per ecoregion. All GAP 1 and 2 protected areas' boundaries were grouped together into continuous areas to facilitate the buffer "distance to" analyses described below. We then analyzed scenario-based land-use conversion threats from logging, agriculture, and development near California's existing protected areas. We did not quantify changes in natural land cover in this portion of our analysis. 
We examined the variation in both amount of protected land and in future land use conversion potential (i.e. from logging, agriculture, and development) by ecoregion. We created a land conversion potential (CP) map based on scenario agreement similar to Wilson et al. (2014). Conversion potential of a cell was calculated as:

$\mathrm{CP} c_{2006-2100}^{P}=\sum \operatorname{LULC} c \Delta_{y 1 \ldots y n}^{P P^{1 \ldots 4}}$

where $\mathrm{CP} c^{P}$ is the conversion potential $(\mathrm{CP})$ projected $(P)$ for each cell $(c)$ over the model period 2006-2100 and $\operatorname{LULC} c \Delta_{y 1 \ldots y n}^{P s^{1 \ldots 4}}$ is the projected land use and land cover (LULC) change in a cell for a given scenario $\left(s^{1 \ldots 4}\right)$ for each year $(y)$ over the modeled period. Conversion potential revealed the degree to which the four scenarios were in agreement on the spatial location of future LULC change. A value of 4 indicated all four scenarios projected a change in LULC for that location, while a value of 0 indicated that none of the scenarios projected a change. Multiple land use conversions were not accounted for in the metric. We assumed that a single land use conversion represented a significant enough departure from starting natural vegetation state to assume fairly permanent alteration.

We analyzed $\mathrm{CP}$ at a range of buffer distances from protected areas at the state level. We buffered each protected area with $1,2,5,10,20$, and $40 \mathrm{~km}$ "distance to" (DT) buffers and classified the resulting DT buffers as 6, 5, $4,3,2,1$, respectively. Similar work used 5, 10, 20, 40, and $50 \mathrm{~km}$ buffer distances in an analysis of land use threats outside of protected areas in the Pacific Northwest (Wilson et al. 2014). Other research analyzed housing density and development within $50 \mathrm{~km}$ of a protected area (Radeloff et al. 2010; Beaumont and Duursma 2012) and within 25$100 \mathrm{~km}$ of protected area borders (Leroux and Kerr 2012). We selected $40 \mathrm{~km}$ as our maximum buffer distance as opposed to $50 \mathrm{~km}$, as a minimal $315 \mathrm{~km}^{2}(0.08 \%)$ of state land area falls more than $40 \mathrm{~km}$ away from a protected area boundary. A conversion threat index (CTI) was then calculated for each cell as:

$\mathrm{CTI} c=\mathrm{CP} c_{2006-2100}^{P} \times \mathrm{DT}^{\mathrm{PA}}$

where $\mathrm{CP} c_{2006-2100}^{P}$ represents the cell's conversion potential over the model period and $\mathrm{DT}^{\mathrm{PA}}$ represents distance to protected area boundary (Wilson et al. 2014). Application of highest DT values nearest protected area boundaries magnified the weight of the DT buffer in calculating the CTI index. Resulting CTI values were classified by quantiles and separated by most common conversion type. Highest CTI values correspond to the highest conversion potential (i.e. greatest number of scenarios agreeing on land use conversion) within closest proximity to protected areas.

\section{Results}

California is home to approximately $96,130 \mathrm{~km}^{2}$ of protected land $(23.5 \%$ of the state) (Table 2$)$. The amount of protected lands within California's ecoregions varied considerably. The Mojave Basin and Range ecoregion had the greatest percent area of protected land (52.2\%), followed by the Sonoran Basin and Range, Central Basin and Range, and the Sierra Nevada. The lowest percentage of protected land area was in the Central California Valley (3.2\%). The forested Cascades, Coast Range, Eastern Cascades, and Klamath Mountains had the greatest land use conversion footprint by percent area across all scenarios. The Central California Valley and Oak Woodlands had the greatest projected land use conversion footprint across scenarios for non-logging related land use change (Table 2).

The economic-oriented scenarios (A1B, A2) projected the highest amounts of LULC change for California by 2100 (Fig. 3). The greatest increase in both developed lands and agriculture were projected in the A2 scenario $\left(45,316 \mathrm{~km}^{2}\right.$ or $14.5 \%$ of the current, unprotected state land area), driven by large-scale increases of development into existing agricultural areas and expansion of agriculture into grassland/shrubland (Fig. 3a, b). Losses of grassland/ shrubland are predominant across scenarios, given demand for developed lands and additional agriculture. Losses of grassland/shrubland ranged from $4.0 \%$ of unprotected state land in $\mathrm{B} 2$ to $13.5 \%$ in $\mathrm{A} 2$. Forest harvest rates were highest in A1B with nearly $20,000 \mathrm{~km}^{2}$ more forest logged than in the lowest harvest B1 scenario (Fig. 3c). In all scenarios, logging on privately owned forests was greater than on all publicly held forested lands. The B2 scenario returned higher rates of logging than $\mathrm{A} 2$, yet the lowest overall amount of LULC change, with only $4.1 \%$ of California's unprotected land area projected to undergo significant land cover conversion (to developed and agriculture).

California's forested Coast Range, Cascades, Eastern Cascades, and Klamath Mountains ecoregions had the highest projected LULC change this century under all scenarios. The Cascades ecoregion, California's smallest by land area, had the highest proportion of projected LULC change across scenarios (Table 2), due to pressures from both logging and development. The Coast Range followed with $48.3-60.4 \%$ of its land area projected to experience change in LULC, while only $13.2 \%$ was protected. The Eastern Cascades was also projected to have high rates of change and had the smallest proportion of protected lands compared to other forest-dominated ecoregions. The Sierra Nevada had the greatest amount of protected lands of any forest-dominated ecoregion and lowest projected LULC change. The Oak Woodlands, the state's largest ecoregion, 
Table 2 California's ecoregions by area $\left(\mathrm{km}^{2}\right)$, amount of protected land in each GAP Status category, and projected land use conversion footprint (\% area) for the IPCC SRES scenarios from 2006 to 2100, representing the total areal amount of projected LULC conversions and not accounting for land projected to convert more than one time (i.e. forest harvest)

\begin{tabular}{|c|c|c|c|c|c|c|c|c|c|}
\hline \multirow[t]{2}{*}{ Ecoregion } & \multirow{2}{*}{$\begin{array}{l}\text { Area } \\
\left(\mathrm{km}^{2}\right)\end{array}$} & \multirow{2}{*}{$\begin{array}{l}\text { GAP } 1 \\
\left(\mathrm{~km}^{2}\right)\end{array}$} & \multirow{2}{*}{$\begin{array}{l}\text { GAP } 2 \\
\left(\mathrm{~km}^{2}\right)\end{array}$} & \multirow{2}{*}{$\begin{array}{l}\text { Total protected } \\
\left(\mathrm{km}^{2}\right)\end{array}$} & \multirow{2}{*}{$\begin{array}{l}\text { Total protected } \\
(\%)\end{array}$} & \multicolumn{4}{|c|}{ Change footprint (\%) } \\
\hline & & & & & & A1B & $\mathrm{A} 2$ & B1 & B2 \\
\hline Cascades & 1,482 & 141 & 21 & 163 & 10.98 & 68.64 & 59.41 & 48.28 & 62.10 \\
\hline Coast Range & 12,988 & 421 & 1,299 & 1,720 & 13.24 & 60.37 & 55.88 & 38.62 & 48.33 \\
\hline Eastern Cascades & 20,655 & 257 & 1,096 & 1,353 & 6.55 & 37.90 & 32.13 & 25.31 & 32.63 \\
\hline Klamath Mountains & 32,904 & 5,104 & 842 & 5,946 & 18.07 & 36.93 & 30.09 & 24.25 & 32.53 \\
\hline Central California Valley & 45,950 & 0 & 1,476 & 1,476 & 3.21 & 24.62 & 26.45 & 18.23 & 31.08 \\
\hline Oak Woodlands & 100,094 & 2,439 & 5,899 & 8,338 & 8.33 & 22.49 & 25.37 & 16.89 & 9.26 \\
\hline Sierra Nevada & 51,852 & 12,800 & 3,076 & 15,876 & 30.62 & 22.26 & 17.52 & 14.42 & 19.44 \\
\hline $\begin{array}{l}\text { Southern California } \\
\text { Mountains }\end{array}$ & 17,911 & 3,477 & 869 & 4,346 & 24.27 & 7.62 & 7.44 & 5.33 & 1.79 \\
\hline Sonoran Basin and Range & 28,277 & 2,248 & 8,965 & 11,213 & 39.66 & 4.58 & 4.53 & 4.09 & 3.84 \\
\hline Mojave Basin and Range & 76,557 & 15,144 & 24,838 & 39,982 & 52.23 & 4.12 & 4.05 & 4.01 & 2.04 \\
\hline Central Basin and Range & 13,141 & 2,713 & 2,127 & 4,840 & 36.83 & 3.23 & 3.38 & 1.26 & 1.36 \\
\hline Northern Basin and Range & 6,421 & 27 & 882 & 909 & 14.15 & 2.85 & 3.46 & 2.00 & 2.08 \\
\hline Total & 408,231 & 44,772 & 51,391 & 96,162 & 23.55 & 19.75 & 19.03 & 14.01 & 15.08 \\
\hline
\end{tabular}

GAP Status 1 areas are permanently protected from conversion of natural land cover and have a mandated management plan in operation to maintain a natural state within which disturbance events are allowed to proceed without interference or are mimicked through management. Areas with GAP Status 2 also have permanent protection from conversion of natural land cover and a mandated management plan in operation to maintain a primarily natural state, but which may receive uses or management practices that degrade the quality of existing natural communities, including suppression of natural disturbance (US Geological Survey, GAP 2012)

had only $8.3 \%$ of its lands protected while LULC change was projected to impact between 9.2 and $22.5 \%$ of ecoregion in the $\mathrm{B} 2$ and $\mathrm{A} 1 \mathrm{~B}$ scenarios, respectively. The Central California Valley was the least protected ecoregion in the state with an extensive land use mosaic and projected increases in both agriculture and developed lands. The four Basin and Range ecoregions had some of the greatest amounts of protected land area and lowest projected LULC changes across all scenarios.

Shifts in forest stand age by 2100 occurred in all scenarios due to increased harvest demand over the modeled period (Fig. 4). In 2006 in the A1B scenario, the majority of forests were comprised of young trees $(40<$ $>120$ years) reflecting current and historical timber harvesting cycles and subsequent regrowth. By 2100 , a shift occurred in all but the B1 scenario, with peaks in forested area in both the youngest trees and those between 160 and 200 years of age. This bi-modal age class pattern reflects a shift to older age stands in protected areas, and in national forest and other public lands, given scenario-based declines in harvest demand. By 2100, the greatest amount of forested land fell into the 160-200 year age class (class 5, Fig. 4) in all but the A1B scenario. The greatest shift to older stand ages occurred in the B1 scenario where environmental protection was highly valued and projected harvest rates were the lowest. High concentrations of old growth ( $>160$ years) were projected for the Klamath
Mountains and Sierra Nevada in all scenarios and throughout California's protected areas.

The top four ecoregions ranked by conversion potential (or $\mathrm{CP}$ hereafter) were the forested ecoregions in the north (Table 3). Over $36.1 \%$ of the Coast Range and $35.8 \%$ of the Cascades will undergo LULC conversion by 2100 . The Sierra Nevada Mountains was the exception, due to the proportionately greater amount of protected area. The Oak Woodlands had the greatest amount of high CP lands $\left(5,458 \mathrm{~km}^{2}\right)$, yet due to its large extent $\left(100,094 \mathrm{~km}^{2}\right)$, this represented less than $5.5 \%$ of overall ecoregion. Projected LULC change in the Central California Valley was more than $5.7 \%$, driven by projected expansion of developed lands and shifts in agriculture. Four percent of unprotected state land had high $\mathrm{CP}(\mathrm{CP}=4)$ within $1 \mathrm{~km}$ of a protected area boundary (Table 4). This increased to $5.7 \%$ of land between 1 and $2 \mathrm{~km}, 6.7 \%$ of land between 2 and $5 \mathrm{~km}$, and $7.5 \%$ between 5 and $10 \mathrm{~km}$. The CP was highest $10-20 \mathrm{~km}$ away from protected areas, where $8.1 \%$ of California's landscape is projected to experience LULC change at least one time in all four scenarios. Approximately $7.8 \%$ of land area within $20-40 \mathrm{~km}$ of protected areas had high CP.

The Coast Range had the highest CTI values by percent land area $(20.5 \%)$, followed by the Cascades $(13.53 \%)$, and Klamath Mountains (5.8\%) (Fig. 5a, b). The Oak Woodlands had the greatest overall land area with high CTI 

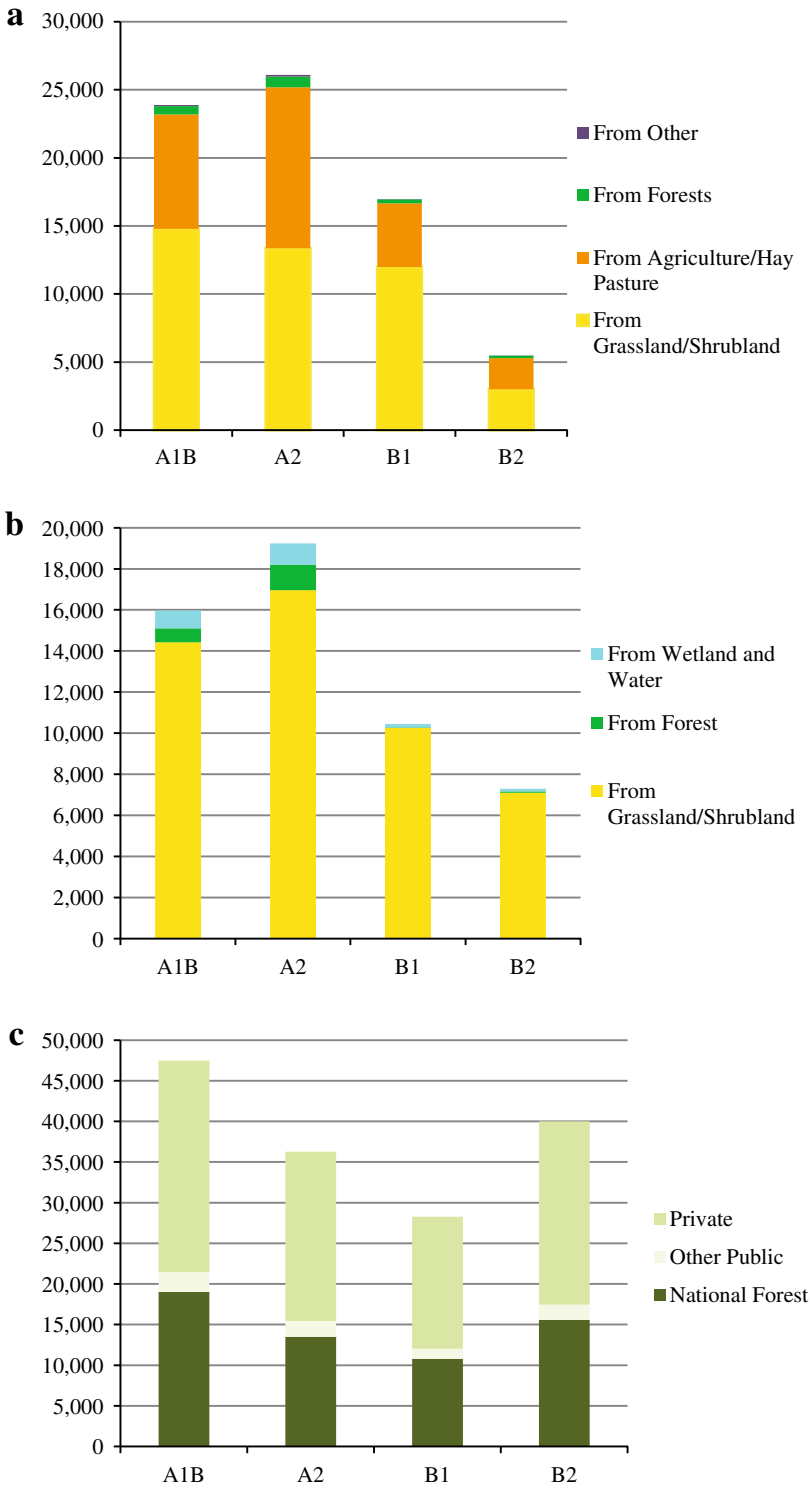

Fig. 3 Total projected California land area conversions between 2006 and 2100 into a developed, $\mathbf{b}$ agriculture, and $\mathbf{c}$ logging for each IPCC SRES scenario. The $x$-axis represents the four scenarios (A1B, $\mathrm{A} 2, \mathrm{~B} 1, \mathrm{~B} 2)$ and the $y$-axis represents land use conversions in square kilometers $\left(\mathrm{km}^{2}\right)$. Land area converting to development is assumed to convert one time and remain in the developed class. Total area values for logging and agriculture can represent land area projected to change multiple times

$\left(4,250 \mathrm{~km}^{2}\right)$, yet this only represented $4.2 \%$ of the ecoregion. When stratified by most common conversion type, highest CTI values for developed conversions occurred in the Oak Woodland and Central California Valley (Fig. 5c). High CTI values related to agriculture conversions also occurred in the Oak Woodlands and Central California Valley (Fig. 5d), while in the Coast Range and Cascades high CTI was associated with forest harvest (Fig. 5e). All other conversion types were primarily located in the Central California Valley (Fig. 5f).

\section{Conclusions}

Resource limitations coupled with accelerated rates of biodiversity loss require more advanced and rapid methods to identify and prioritize threatened sites (Menon et al. 2001) and future conservation targets (Newburn et al. 2005). Scenario-based, spatially explicit LULC projections are emerging as a useful tool for identifying protected areas at greater risk of proximal land conversion. Combining protection level status with patterns of land use threat helps target protected areas at greater risk and enables land managers the ability to refine conservation strategies (Theobald 2003). Our CTI index provides an indicator of conservation land vulnerability needed for biodiversity planning and assessment (Stoms 2000) and identifies target areas for additional protection in California's vulnerable ecosystems. According to this analysis, the Coast Range ecoregion will be most threatened in this century with more than $20 \%$ of its landscape falling within the high CTI category and only $13 \%$ of its land protected. The Central California Valley is vulnerable as well, given it had the least amount of protected land and is already dominated by intensive land use. The Oak Woodlands also emerged as highly vulnerable with the largest total land area with high conversion potential and highest development-related CTI values.

Future changes in land use and land cover, coupled with a changing climate, will likely challenge the integrity and stability of protected areas in California this century. Our ecoregion-based results show the Coast Range, Cascades, and Klamath Mountains with the highest projected footprint of land use change by 2100 in close proximity to protected area boundaries. However, land use change in these ecoregions is predominantly related to forestry and does not represent a full departure from natural conditions. In all scenarios, forest stand age increases, with the oldest trees found in protected areas of the Sierra Nevada and Klamath Mountains. It must again be noted that natural disturbances were not modeled. For more permanent land use conversions into agriculture and developed uses, our CTI results indicate protected areas in the Central California Valley and Oak Woodlands are most vulnerable. Under all four IPCC emission LULC scenarios, future anthropogenic land use demand leads to degradation and loss of source ecosystem reserves which will likely alter species-area relationships within existing protected areas, possibly leading to species decline (Hansen and DeFries 2007). The grassland/shrubland class is projected to experience the greatest decline in total extent due to intensive land use (i.e. from agriculture and development). The amount of protected land designated in California's grassland/shrubland-dominated ecoregions is also relatively low. Additional protection of land in these underrepresented communities would appear warranted. 

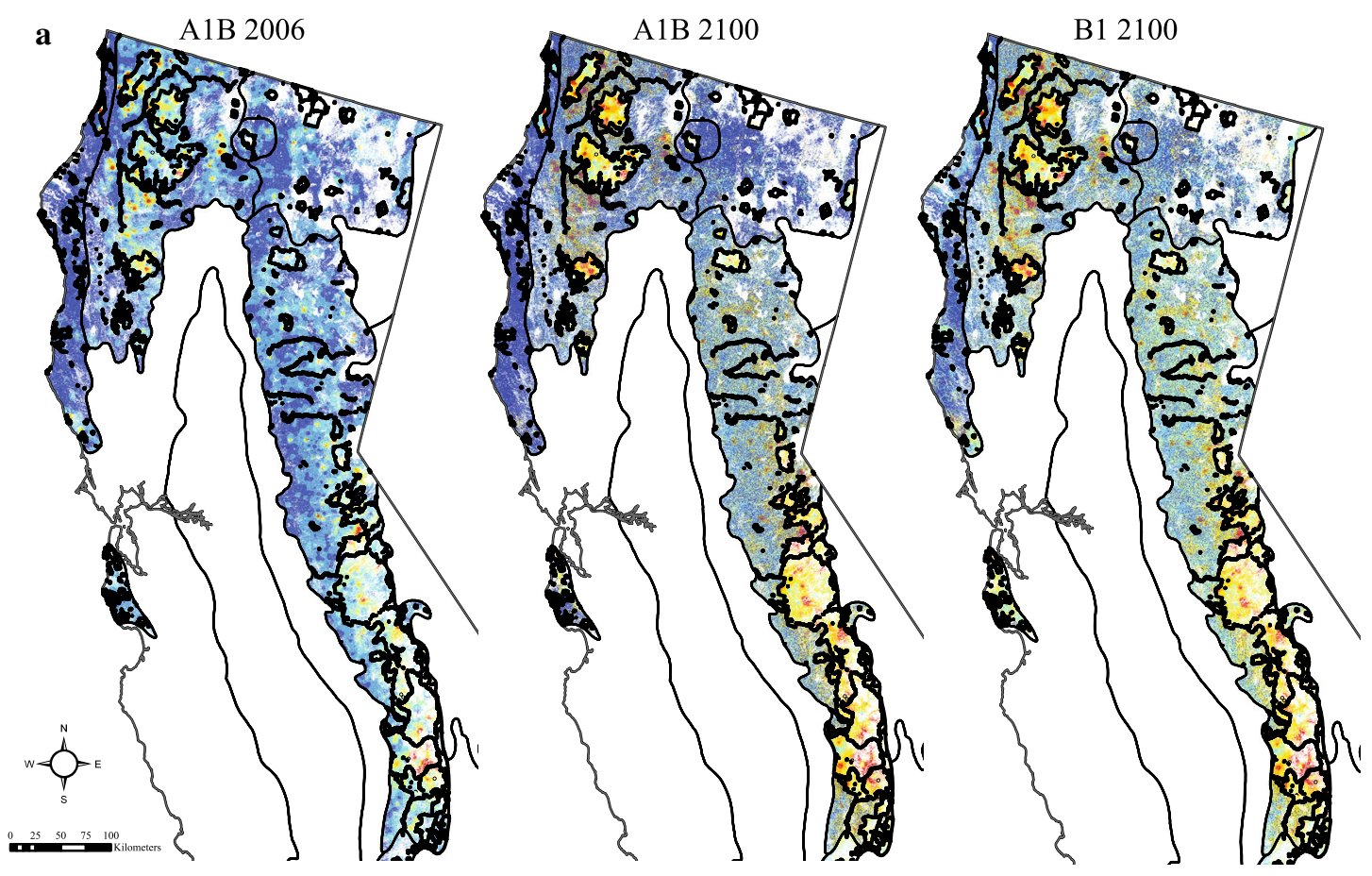

Age class
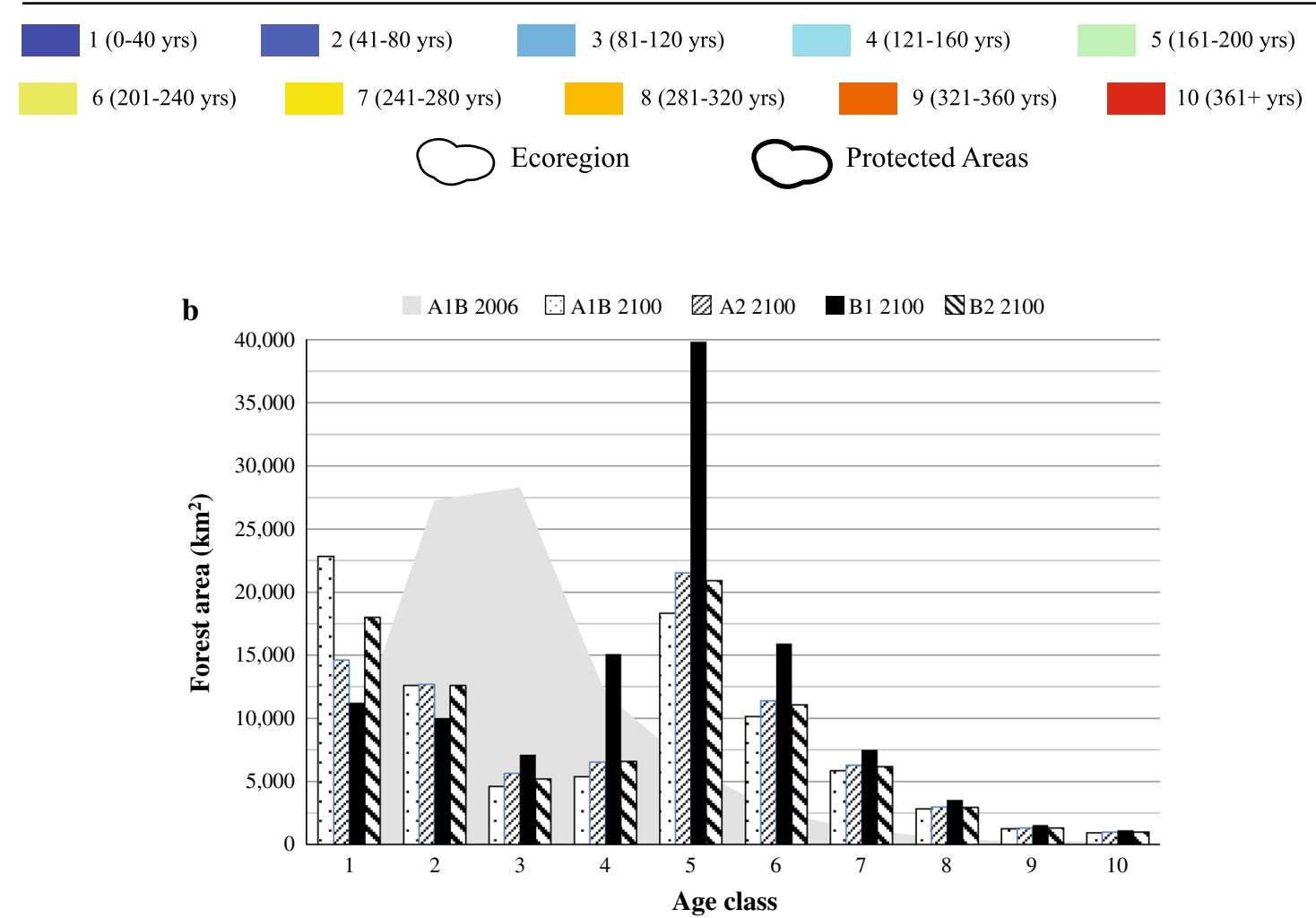

Fig. 4 Forest stand age from 2006 to 2100, where a represents stand $\left(\mathrm{km}^{2}\right)$ within 10 different 40-year stand age classes (age class 10 age in the A1B scenario in 2006 (business as usual) and 2100 includes trees $361+$ years old) for A1B in 2006 (grey area, business compared to the B1 scenario in 2100 and $\mathbf{b}$ is the total forested area as usual) and in 2100 (columns) for the four IPCC SRES scenarios 
Table 3 Projected land use conversion potential $(\mathrm{CP})$ across four scenarios in California's ecoregions expressed in square kilometers $\left(\mathrm{km}^{2}\right)$ and percent (\%) total area

\begin{tabular}{lcrrrrr}
\hline Ecoregion & No change $\left(\mathrm{km}^{2}\right)$ & \multicolumn{3}{l}{ Conversion potential $(\mathrm{CP})$} & \multicolumn{2}{l}{$\begin{array}{l}\text { Land area } \\
\text { changing } \\
\text { in all scenarios }(\%)\end{array}$} \\
\cline { 3 - 7 } & & $1\left(\mathrm{~km}^{2}\right)$ & $2\left(\mathrm{~km}^{2}\right)$ & $3\left(\mathrm{~km}^{2}\right)$ & $4\left(\mathrm{~km}^{2}\right)$ & \\
\hline Coast Range & 4,673 & 1,038 & 1,224 & 1,370 & 4,688 & 36.08 \\
Cascades & 388 & 65 & 154 & 343 & 530 & 35.80 \\
Eastern Cascades & 10,659 & 2,074 & 2,227 & 2,861 & 2,837 & 13.73 \\
Klamath Mountains & 15,120 & 4,870 & 5,540 & 4,652 & 2,714 & 8.25 \\
Central California Valley & 22,247 & 10,582 & 6,392 & 4,098 & 2,628 & 5.72 \\
Oak Woodlands & 69,821 & 7,490 & 7,152 & 10,168 & 5,458 & 5.45 \\
Sierra Nevada & 31,409 & 8,914 & 6,873 & 3,096 & 1,564 & 3.02 \\
Southern CA Mountains & 16,140 & 550 & 508 & 464 & 254 & 1.42 \\
Mojave Basin and Range & 71,714 & 1,730 & 977 & 1,336 & 797 & 1.04 \\
Sonoran Basin and Range & 25,554 & 1,422 & 686 & 420 & 192 & 0.68 \\
Northern Basin and Range & 5,962 & 314 & 97 & 26 & 23 & 0.36 \\
Central Basin and Range & 12,331 & 517 & 203 & 65 & 25 & 0.19 \\
\hline
\end{tabular}

Table 4 Projected land use conversion potential $(\mathrm{CP})$ across four scenarios in California by distance to (DT) buffer zones in square kilometers $\left(\mathrm{km}^{2}\right)$ and percent $(\%)$ total area

\begin{tabular}{|c|c|c|c|c|c|c|c|c|}
\hline \multirow[t]{3}{*}{ Distance to (DT) buffer (km) } & \multicolumn{8}{|c|}{ Conversion potential } \\
\hline & \multicolumn{2}{|l|}{1} & \multicolumn{2}{|l|}{2} & \multicolumn{2}{|l|}{3} & \multicolumn{2}{|l|}{4} \\
\hline & $\mathrm{km}^{2}$ & $\%$ & $\mathrm{~km}^{2}$ & $\%$ & $\mathrm{~km}^{2}$ & $\%$ & $\mathrm{~km}^{2}$ & $\%$ \\
\hline 1 & 3,033 & 9.47 & 2,480 & 7.74 & 1,941 & 6.06 & 1,298 & 4.05 \\
\hline 2 & 3,151 & 11.20 & 2,672 & 9.50 & 2,172 & 7.72 & 1,610 & 5.72 \\
\hline 5 & 9,001 & 11.86 & 7,634 & 10.06 & 6,606 & 8.70 & 5,055 & 6.66 \\
\hline 10 & 11,479 & 13.23 & 9,291 & 10.71 & 8,732 & 10.06 & 6,513 & 7.51 \\
\hline 20 & 9,686 & 13.75 & 7,672 & 10.89 & 7,355 & 10.44 & 5,713 & 8.11 \\
\hline 40 & 2,951 & 16.03 & 2,061 & 11.19 & 1,962 & 10.66 & 1,445 & 7.85 \\
\hline
\end{tabular}

The extent, magnitude, and intensity of human land use in and around protected areas will dictate best management approaches to balance ecological function with human needs (DeFries et al. 2007). The ability to manage land use intensity outside of protected areas will be critical to conserving species richness (Beaumont and Duursma 2012; Butsic et al. 2012; Hansen and DeFries 2007) and may prove critical to meet long-term conservation objectives (Leroux and Kerr 2012). The two goals of systematic conservation planning are representativeness and persistence (Margules and Pressey 2000). Representativeness refers to the need of biodiversity reserves, or protected areas, to best represent biodiversity at all levels of organization (Margules and Pressey 2000). Persistence refers to the ability of protected areas to promote the longterm survival of species by maintaining natural processes, viable populations, and excluding threats (Margules and Pressey 2000). According to our CTI results, protected areas in the Central California Valley, Eastern Cascades, and Oak Woodlands have a low likelihood of meeting persistence goals. In these ecoregions, biodiversity protection is limited and current and projected land use are high. These ecoregions were also assigned high biodiversity vulnerability by Klausmeyer et al. (2011). Protected areas least likely to meet persistence goals include protected areas in the Los Angeles Basin of the Oak Woodlands, in the mostly privately-held Coast Range forests, and in the Eastern Cascades where protected areas are few, yet scenario projections show the third highest land use conversion footprint by century's end.

While future land use scenarios are not absolute outcomes, they do represent plausible future conditions based on scenario assumptions, guided by expert opinion, quantified by land-use histories, and spatially constrained via probability surfaces (Sleeter et al. 2012a, 2013; Sohl et al. 2014). The strength of spatially explicit land use allocation models is their ability to determine the suitability of the land to support a given LULC type, based on

Fig. 5 Conversion threat index (CTI) for a California for 2006-2100, with high CTI values corresponding to areas with the highest projected conversion potential (most scenario agreement) within closest proximity to a protected area boundary and $\mathbf{b}$ percent of ecoregion area by CTI value; CTI values by most common conversion type between 2006 and 2100 for $\mathbf{c}$ developed conversions, $\mathbf{d}$ agriculture conversions, e logging conversions, and $\mathbf{f}$ all other conversions 

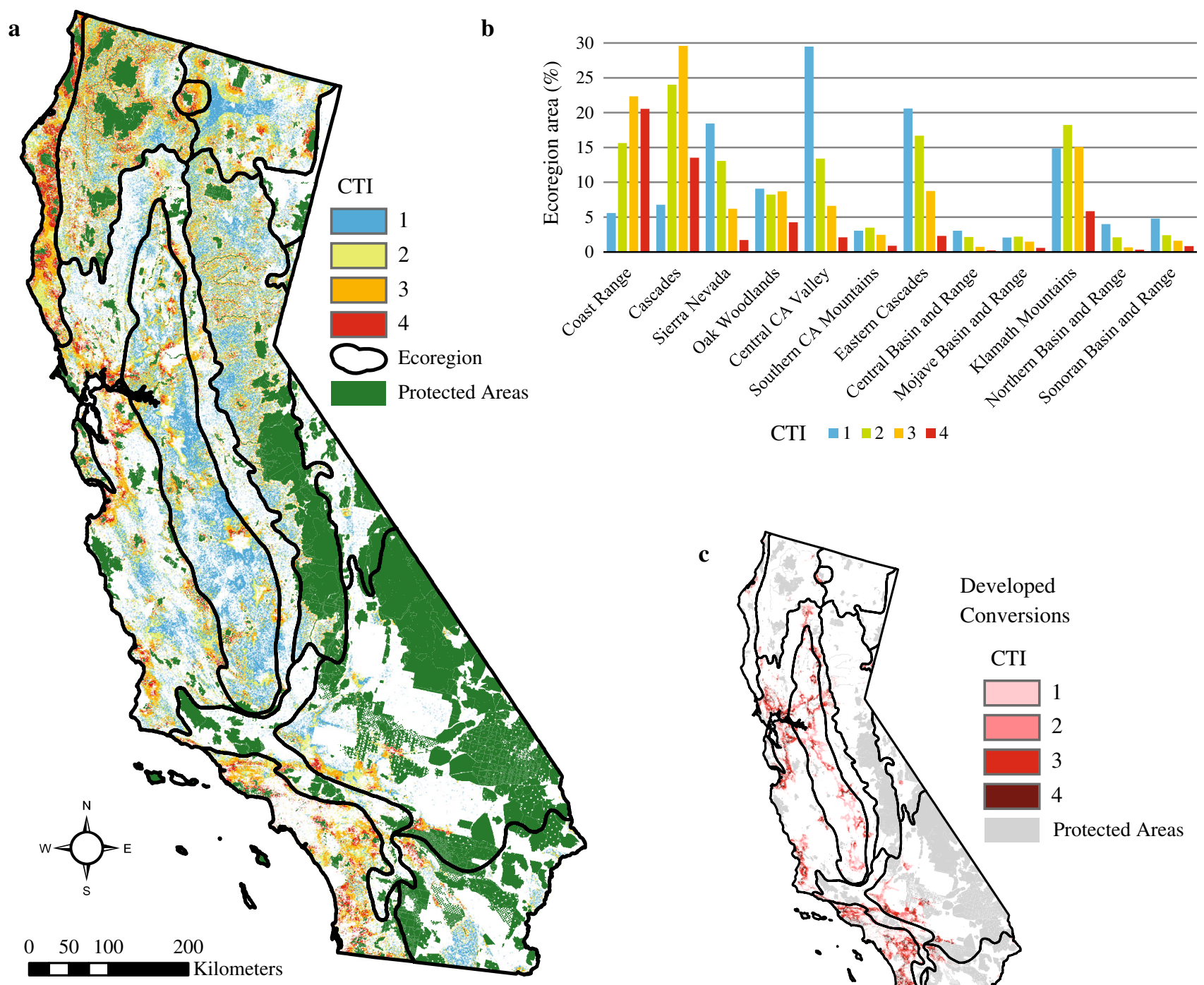

c
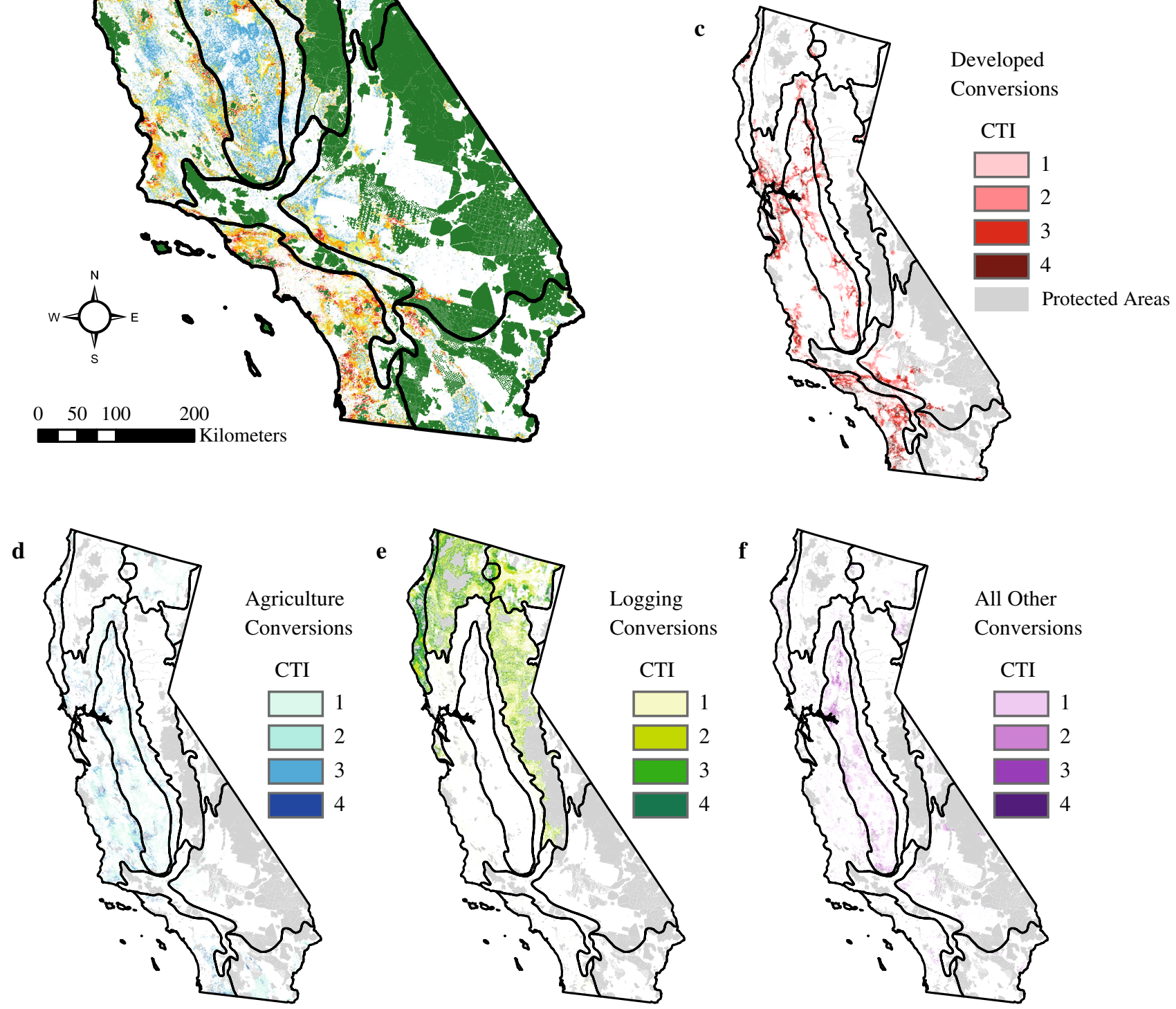
biophysical parameters (Moreira et al. 2009). The weakness of this modeling approach is the inability to track all sources of uncertainty in the modeling framework. Multidecadal land use predictions are fraught with uncertainty, as future socioeconomic conditions and technological change are impossible to predict (Radeloff et al. 2012). Our coarse-scale analysis does not attempt to disentangle the implications of future land use on individual species, populations, or species-area effects or the varying impacts by land use type. However, our conversion threat index should be useful for a variety of finer scale species and population specific analyses, where more detailed data on species-specific disturbance response exists. The CTI index can be easily incorporated into more localized analyses at the individual protected area unit or community level as well as broader scale habitat and corridor analyses, such as California's Essential Habitat Connectivity Project data (Spencer et al. 2010). However, given the LULC modeling results did not report on model uncertainty, additional analysis using existing data, did not seem appropriate at this time. Future efforts to model land use which incorporate estimates of model uncertainty will be better suited for more detailed CTI spatial analysis and location specific recommendations. Despite these limitations, spatially explicit, scenario-based LULC data can be useful to land managers in visualizing alternative landscape futures. When multiple scenarios are combined, reflecting spatial agreement, areas with a higher probability of LULC conversion are highlighted and proximity measures to protected area boundaries can be calculated, revealing protected areas most vulnerable to regional LULC change.

Acknowledgments This work was funded by the US Geological Survey's Climate and Land Use Change Research and Development Program. We would like to thank Jason Kreitler and Mara Tongue of the US Geological Survey for their careful and thoughtful review of the manuscript. We also thank the anonymous reviewers for their detailed and meticulous reviews which significantly strengthened the manuscript. A final thank you to Gabriele Götz, managing editor at Regional Environmental Change, and all the supporting editorial staff who helped usher the authors through the publication process.

Open Access This article is distributed under the terms of the Creative Commons Attribution License which permits any use, distribution, and reproduction in any medium, provided the original author(s) and the source are credited.

\section{References}

Anderson JR, Hardy EE, Roach JT, Witmer RE (1976) A land use and land cover classification scheme for use with remote sensor data. US Geological Survey Professional Paper 964. http://pubs.er. usgs.gov/publication/pp964

Arnell NW, Livermore MJL, Kovats S, Levy P (2004) Climate and socioeconomic scenarios for global-scale climate change impacts assessments: characterizing the SRES storylines. Glob Environ Chang 14:3-20

Beaumont LJ, Duursma D (2012) Global projections of 21st century land-use changes in regions adjacent to protected lands. PLoS One 7(8):e43714. doi:10.1371/journal.pone.0043714

Bierwagen BG, Theobald DM, Pyke CR, Choate A, Groth P, Thomas JV, Morefield P (2010) National housing and impervious surface scenarios for integrated climate impact assessments. PNAS 107:20887-20892

Bonan GB (1997) Effects of land use on the climate of the United States. Clim Chang 37:449-486

Butsic V, Radeloff VC, Kuemmerle T, Pidgeon AM (2012) Analytical solutions to trade-offs between size of protected areas and land-use intensity. Conserv Biol 26:883-893

Bytnerowicz A, Tausz M, Alonso R, Jones D, Johnson R, Grulke N (2002) Summer-time distribution of air pollutants in Sequoia National Park, California. Environ Pollut 111:187-203

Charbonneau R, Kondolf GM (1993) Land use change in California, USA: nonpoint source water quality impacts. Environ Manag $17: 453-460$

Cole DN, Landres PB (1996) Threats to wilderness ecosystems: impacts and research needs. Ecol Appl 6:168-184

Dale VH (1997) The relationship between land-use change and climate change. Ecol Appl 7:753-769

Davies RG, Orme CDL, Olson V, Thomas GH, Ross SG, Ding T-S, Rasmussen PC, Stattersfield AJ, Bennett PM, Blackburn TM, Owens IPF, Gaston KJ (2006) Human impacts and the global distribution of extinction risk. Proc $\mathrm{R}$ Soc Biol Sci 273:2127-2133. doi:10.1098/rspb.2006.3551

DeFries R, Hansen A, Turner BL, Reid R, Liu J (2007) Land use change around protected areas: management to balance human needs and ecological function. Ecol Appl 17:1031-1038

Fenn ME, Haeuber R, Tonnesen GS, Baron JS, Grossman-Clark S, Hope D, Jaffe DA, Copeland S, Geiser L, Rueth HM, Sickman JO (2003) Nitrogen emissions, deposition, and monitoring in the Western United States. BioSci 53:391-403

Fischer J, Lindenmayer DB (2007) Landscape modification and habitat fragmentation: a synthesis. Glob Ecol Biogeogr 16:265-280

Foley JA, DeFries R, Asner GP, Barford C, Bonan G, Carpenter SR, Chapin FS, Coe MT, Daily GC, Gibbs HK, Helkowski JH, Holloway T, Howard EA, Kucharik CJ, Monfreda C, Patz JA, Prentice C, Ramankutty N, Snyder Pk (2005) Global consequences of land use. Science 309:570-574

Gaffin SR, Rosenzweig C, Xing X, Yetman G (2004) Downscaling and geo-spatial gridding of socio-economic projections from the IPCC special report on emissions scenarios (SRES). Glob Environ Chang 14:105-123

Gallant AL, Loveland TR, Sohl TL, Napton D (2004) Using a geographic framework for analyzing land cover issues. Environ Manag 34:89-110

Hamilton CM, Martinuzzi S, Plantinga AJ, Radeloff VC, Lewis DJ, Thogmartin WE, Heglund PJ, Pidgeon AM (2013) Current and future land use around a nationwide protected area network. PLoS One 8(1):e55737. doi:10.1371/journal.pone.0055737

Hansen AJ, DeFries R (2007) Ecological mechanisms linking protected areas to surrounding lands. Ecol Appl 17:974-988

Hansen AJ, Rotella JJ (2002) Biophysical factors, land use, and species viability in and around nature reserves. Conserv Biol 16:1112-1122

Hansen AJ, Rasker R, Maxwell B, Rotella JJ, Johnson JD, Parmenter AW, Langner U, Cohen WB, Lawrence RL, Kraska MPV (2002) Ecological causes and consequences of demographic change in the new west. Bioscience 52:151-162

Hansen AJ, Piekielek N, Davis C, Hass J, Theobald DM, Gross JE, Monahan WB, Olliff T, Running SW (2014) Exposure of US 
National Parks to land use and climate change 1900-2100. Ecol Appl 24:484-502

Heistermann M, Muller C, Ronneberger K (2006) Land in sight? Achievements, deficits, and potentials of continental to global scale land-use modeling. Agric Ecosyst Environ 114:141-158

Houghton RA, Hackler JL (2001) Carbon flux to the atmosphere from land-use changes: 1850-1990. ORNL/CDIAC-131, NDP-050/ R1. Carbon dioxide Information Analysis Center, US Department of Energy, Oak Ridge National Laboratory, Oak Ridge, Tennessee, USA doi:10.3334/CDIAC/lue.ndp050

Huang C, Goward SN, Masek JG, Thomas N, Zhu Z, Vogelmann JE (2010) An auto-mated approach for reconstructing recent forest disturbance history using dense Landsat time series stacks. Remote Sens Environ 114:183-198

IMAGE Team (2001) The IMAGE 2.2 implementation of the SRES scenarios: a comprehensive analysis of emissions, climate change and impacts in the 21st century. In: RIVM CD-ROM Publication 481508018, National Institute for Public Health and the Environ, Bilthoven, The Netherlands http://www.rivm.nl/ bibliotheek/rapporten/481508018.html

Joppa LN, Loarie SR, Pimm SL (2008) On the protection of "protected areas". Proc Natl Acad Sci USA 105:6673-6678

Klausmeyer KR, Shaw MR (2009) Climate change, habitat loss, protected areas and the climate adaptation potential of species in Mediterranean ecosystems worldwide. PLoS One 4:e6392

Klausmeyer KR, Shaw MR, MacKenzie JB, Cameron DR (2011) Landscape-scale indicators of biodiversity's vulnerability to climate change. Ecosphere 2:1-18

Lawrence PL, Chase TN (2010) Investigating the climate impacts of global land cover change in the community climate system model. Int J Clim 30:2066-2087. doi:10.1002/joc.2061

LeNoir JS, McConnell LL, Fellers GM, Cahill TM, Seiber JN (2009) Summertime transport of current-use pesticides from California's central valley to the Sierra Nevada mountain range, USA. Environ Toxicol Chem 18:2715-2722

Leroux SJ, Kerr JT (2012) Land development in and around protected areas at the wilderness fronteir. Conserv Biol 27:166-176

Luoto M, Virkkala R, Heikkinen RK (2007) The role of land cover in bioclimatic models depends on spatial resolution. Glob Ecol Biogeogr 16:34-42

Margules CR, Pressey RL (2000) Systematic conservation planning. Nature 405:243-253

Maurer EP, Brekke L, Pruitt T, Duffy PB (2007) Fine-resolution climate projections enhance regional climate change impact studies. EOS 88:504

McDonald RI, Yuan-Farrell C, Fievet C, Moeller M, Kareiva P, Foster D, Gragson T, Kinzig A, Kuby L, Redman C (2007) Estimating the effect of protected lands on the development and conservation of their surroundings. Conserv Biol 21:1526-1536. doi:10.1111/j.1523-1739.2007.00799.x

Menon S, Pontius RG, Rose J, Khan ML, Bawa KS (2001) Identifying conservation-priority areas in the tropics: a land-use change modeling approach. Conserv Biol 15:501-512

Moreira E, Costa S, Aguiar AP (2009) Dynamical coupling of multiscale land change models. Landsc Ecol 24:1183-1194

Myers N (1990) The biodiversity challenge: expanded hot-spots analysis. Environmentalist 10:243-256

Nakicenovic N, Swart R (eds) (2000) IPCC Special Report on Emission Scenarios. Cambridge University Press, Cambridge, UK. http:// www.ipcc.ch/ipccreports/sres/emission/index.php?idp=0

Natural Resources Conservation Service (2011) Soil Survey Geographic (SSURGO) Database: US Department of Agriculture, Available at: http://soildatamart.nrcs.usda.gov

Nave LE, Vance ED, Swanston CW, Curtis PS (2010) Harvest impacts on soil carbon storage in temperate forests. Forest Ecol Manag 259:857-866
Neary DG, Hornbeck JW (1994) Impacts of Harvesting and Associated Practices on Off-Site Environmental Quality. In: Dyck WJ, Cole DW, Comerford NB (eds) Impacts of forest harvesting on long-term site productivity, 1st edn. Chapman and Hall, London, pp 81-118

Newburn D, Reed S, Berck P, Merenlender A (2005) Economics and land-use change in prioritizing private land conservation. Conserv Biol 19:1411-1420

Omernik JM (1987) Ecoregions of the conterminous United States. Ann Assoc Am Geogr 77:118-125

Pielke RA, Marland G, Betts RA, Chase TN, Eastman JL, Niles JO, Niyogi DDS, Running SW (2002) The influence of land-use change and landscape dynamics on the climate system: relevance to climate-change policy beyond the radiative effect of greenhouse gases. Philos Trans R Soc Lond 360:1705-1719

Pitman AJ, Avila FB, Abramowitz G, Wang YP, Phipps SJ, de Noblet-Ducoudré N (2011) Importance of background climate in determining the impact of land-cover change on regional climate. Nat Clim Chang 1:472-475. doi:10.1038/ NCLIMATE1294

Radeloff VC, Stewart SI, Hawbaker TJ, Gimmi U, Pidgeon AM, Flather CH, Hammer RB, Helmers DP (2010) Housing growth in and near United States protected areas limits their conservation value. Proc Natl Acad Sci USA 107:940-945

Radeloff VC, Nelson E, Plantinga AJ, Lewis DJ, Helmers D, Lawler JJ, Withey JC, Beaudry F, Martinuzzi S, Butsic V, Lonsdorf E, White D, Polasky S (2012) Economic-based projections of future land use in the conterminous United States under alternative policy scenarios. Ecol Appl 22:1036-1049

Rittenhouse CD, Pidgeon AM, Albright TP, Culbert PD, Clayton MK, Flather CH, Masek JG, Radeloff VC (2012) Land-cover change and avian diversity in the conterminous United States. Conserv Biol 26:821-829

Romero H, Ihl M, Rivera A, Zalazar P, Azocar P (1999) Rapid urban growth, land-use changes and air pollution in Santiago, Chile. Atmos Environ 33:4039-4047

Ross Z, English PB, Scalf R, Gunier R, Smorodinsky S, Wall S, Jerrett M (2006) Nitrogen dioxide prediction in Southern California use land use regression modeling: potential for environmental health analyses. J Expo Sci Environ Epidemiol 16:106-114

Rounsevell MDA, Reginster I, Araújo MB, Carter TR, Dendoncker N, Ewert F, House JI, Kankaanpää S, Leemans R, Metzger MJ, Schmit C, Smith P, Tuck G (2006) A coherent set of future land use change scenarios for Europe. Agric Ecosyst Environ 114:57-68

Sala OE, Chapin FS, Armesto JJ, Berlow E, Bloomfield J, Dirzo R, Huber-Sanwald E, Huenneke LF, Jackson RB, Kinzig A, Leemans R, Lodge DM, Mooney HA, Oesterheld M, Poff NL, Sykes MT, Walker BH, Walker M, Wall DH (2000) Global biodiversity scenarios for the year 2100. Science 287:1770-1774

Seabloom EW, Dobson AP, Stoms DM (2002) Extinction rates under nonrandom patterns of habitat loss. PNAS 99:11229-11234

Sleeter BM, Wilson TS, Soulard CE, Liu J (2010) Estimation of late 20th century land-cover change in California. Environ Monit Assess 173:251-266

Sleeter BM, Sohl TL, Bouchard MA, Reker RR, Soulard CE, Acevedo W, Griffith GE, Sleeter RR, Auch RF, Sayler, KL, Prisley S, Zhu Z (2012a) Scenarios of land use and land cover change in the conterminous Unites States: Utilizing the special report on emission scenarios at ecoregional scales. Glob Environ Chang 22:896-914

Sleeter BM, Sohl TL, Wilson TS, Sleeter RR, Soulard CE, Bouchard MA, Sayler KL, Reker RR, Griffith GE (2012b) Projected landuse and land-cover change in the Western United States. In: Zhu $\mathrm{Z}$, Reed BC (eds) Baseline and projected future carbon storage 
and greenhouse-gas fluxes in ecosystems of the Western United States. US Geological Survey Professional Paper 1797, Reston, VA, pp 65-86. http://pubs.usgs.gov/pp/1797/

Sleeter BM, Sohl TL, Loveland TR, Auch RF, Acevedo W, Drummond MA, Sayler KL, Stehman SV (2013) Land-cover change in the conterminous United States from 1973-2000. Glob Environ Chang. doi:10.1016/j.gloenvcha.2013.03.006

Sohl TL, Sayler KL, Drummond MA, Loveland TR (2007) The FORE-SCE model: a practical approach for projecting land use change using scenario-based modeling. J L Use Sci 2:103-126. doi:10.1080/17474230701218202

Sohl TL, Sleeter BM, Sayler KL, Bouchard MA, Reker RR, Bennett SL, Sleeter RR, Kanengieter RL, Zhu Z (2012a) Spatially explicit land-use and land-cover scenarios for the great plains of the United States. Agric Ecosyst Environ 153:1-15

Sohl TL, Sleeter BM, Zhu Z, Sayler KL, Bennett S, Bouchard M, Reker R, Hawbaker T, Wein A, Liu S, Kanengieter R, Acevedo W (2012b) A land-use and land-cover modeling strategy to support a national assessment of carbon stocks and fluxes. Appl Geogr 34:111-124

Sohl TL, Sayler KL, Bouchard MA, Reker RR, Friesz AM, Bennett SL, Sleeter BM, Sleeter RR, Wilson TS, Soulard C, Knuppe M, Van Hofwegen $T$ (2014) Spatially explicit modeling of 1992-2100 land cover and forest stand age for the conterminous United States. Ecol Appl 24:1015-1036

Soule ME (2001) Conservation: tactics for a constant crisis. Science 253:744-750

Spencer, WD, Beier, P, Penrod, K, Winters, K, Paulman C, RustigianRomsos H, Strittholt J, Parisi M, Pettler A (2010) California essential habitat connectivity project: a strategy for conserving a connected California. Prepared for California Department of Transportation, California Department of Fish and Game, and Federal Highways Administration. http://www.wildcalifornia. org/wp-content/uploads/2014/04/CEHC_Plan_MASTER_030210 _3-reduced.pdf

State of California (2013) Department of Finance, Report P-1 (County): State and County Total Population Projections, 2010-2060. Sacramento, California. http://www.dof.ca.gov/ research/demographic/reports/projections/p-1/

Stoms DM (2000) GAP management status and regional indicators of threats to biodiversity. Landsc Ecol 15:21-33

Strayer DL, Beighley RE, Thompson LC, Brooks S, Nilsson C, Pinay G, Naiman RJ (2003) Effects of land cover on stream ecosystems: roles of empirical models and scaling issues. Ecosyt 6:407-423

Takemoto BK, Bytnerowicz A, Fenn ME (2001) Current and future effects of ozone and atmospheric nitrogen deposition on California's mixed conifer forests. For Ecol Manag 144:159173. doi:10.1016/S0378-1127(00)00368-6

Theobald DM (2003) Targeting conservation action through assessment of protection and exurban threats. Conserv Biol 17:16241637

Turner BL II, Clark WC, Kates RM, Richards JF, Mathews JT, Meyer WB (eds) (1990) The Earth as transformed by human action: global and regional changes in the biosphere over the past 300 years. Cambridge University Press, Cambridge, p 713. ISBN: 0521363578

US Census Bureau (2000) TIGER/Line Files 2000. Available from: https://www.census.gov/geo/maps-data/data/tiger-line.html

US Census Bureau (2013) State and County QuickFacts. Available from http://quickfacts.census.gov/qfd/states/06000.html. Accessed 12 June 2013
US Environmental Protection Agency (1999) Level III ecoregions of the continental United States: Corvallis, Oregon. US Environmental Protection Agency, National Health and Environmental Effects Research Laboratory. Digital map, scale 1:250,000. Available from: http://www.epa.gov/wed/pages/ecoregions/level_ iii_iv.htm

US Forest Service (2011) Forest inventory and analysis national program: US Department of Agriculture, Forest Service database. Available from http://www.fia.fs.fed.us/tools-data. Accessed 15 Nov 2011

US Geological Survey (2006) National elevation dataset: Available from: http://ned.usgs.gov/

US Geological Survey GAP (2012) Protected areas database of the United States (PAD-US), version 1.3 Combined Feature Class http://gapanalysis.usgs.gov/padus/data/metadata/

US Geological Survey (2012) National Atlas of the United States: Available from: http://nationalatlas.gov/

van Vuuren DP, Lucas PL, Hilderink H (2007) Downscaling drivers of global environmental change scenarios: enabling use of the IPCC-SRES scenarios at the national and grid level. Glob Environ Chang 17:114-130

Verburg PH, Schulp CJE, Witte N, Veldkamp A (2006) Downscaling of land use change scenarios to assess the dynamics of European landscapes. Agric Ecosyst Environ 114:39-56

Vitousek PM, Mooney HA, Lubchenco J, Melillo JM (1997) Human domination of earth's ecosystems. Science 277:494-499

Wade AA, Theobald DM, Laituri MJ (2011) A multi-scale assessment of local and contextual threats to existing and potential US protected areas. Landscape Urban Plan 101:215-227

Wear DN (2011) Forecasts of county-level land uses under three future scenarios: a technical document supporting the Forest Service 2010 RPA Assessment, Gen. Tech. Rep. SRS-141. Asheville, NC. US Department of Agriculture Forest Service, Southern Research Station, p 41 Available from: http://www.srs. fs.usda.gov/pubs/gtr/gtr_srs141.pdf

White D, Minotti PG, Barczak MJ, Sifneos JC, Freemark KE, Santelmann MV, Steinitz CF, Kiester AR, Preston EM (1997) Assessing risks to biodiversity from future landscape change. Conserv Bio 11:349-360. doi:10.1046/j.1523-1739.1997.95458.x

Wilson K, Pressey RL, Newton A, Burgman M, Possingham H, Weston C (2005) Measuring and incorporating vulnerability into conservation planning. Environ Manag 35:527-543

Wilson TS, Sleeter BS, Sohl TL, Griffith GE, Acevedo W, Bennett S, Bouchard M, Reker R, Ryan C, Sayler KL, Sleeter RR, Soulard CE (2012) Future scenarios of land-use and land-cover change in the United States: The Marine West Coast Forests Ecoregion. US Geological Survey Open File Report 2012-1252, p 14 and data files:http://pubs.usgs.gov/of/2012/1252/

Wilson TS, Sleeter BS, Sleeter RR, Soulard CE (2014) Land-use threats and protected areas: a scenario-based, landscape level approach. Land 3:362-389

Zhao S, Liu S, Sohl T, Young C, Werner J (2013) Land use and carbon dynamics in the southeastern United States from 1992 to 2050. Environ Res Lett 8:044022, p 9. doi:10.1088/1748-9326/8/ $4 / 044022$

Zhu Z (ed) (2011) Baseline and projected future carbon storage and greenhouse-gas fluxes in the great plains region of the United States, US Geological Survey Professional Paper 1787, p 28. http://pubs.usgs.gov/pp/1787/ 